\title{
Online Learning Collaboration with Assisted Learning Models in Technical Drawing Subjects for Vocational Students
}

\author{
M. Agphin Ramadhan", Arris Maulana, Nala Saka Ocean Setiani, Daryati \\ Universitas Negeri Jakarta \\ *Corresponding author. Email: agphin@unj.ac.id
}

\begin{abstract}
Due to the COVID-19 pandemic situation, online learning is the new norm in education. However, this long-distance system has become a challenge not only for teachers but also for the students. By using assisted learning model, this classroom action research aims to improve students' learning activities during the Engineering Drawing topic. The subject of this research is the first year of Construction and Property Business Skills Competency Class at Vocational High School Jakarta for the 2020/2021 academic year with 16 students who are using the autocad application to draw. There are 2 cycles in this classroom action research. Interview, observation, documentation, and field notes were used to collect data. Based on the result of the research, the average score of students' involvement in class activities at the end of cycle two was 56,26\% and showed an increase in the score of $14.39 \%$ from the previous cycle, which was $41.86 \%$. From the research results that have been described previously, it can be concluded that students' learning activities while learning Technical Drawing with the assisted learning model are increasing.
\end{abstract}

Keywords: assisted learning, online learning, technical drawing, vocational students.

\section{INTRODUCTION}

The pandemic of COVID-19 which emerged in 2020 is not only had an impact on the worlds' economic sector, but also had a huge impact on the world of education. Face-to-face learning is now shifting to an online system where the students are required to study from home due to the mandatory social distancing [1]. Teachers are required to have a better understanding of how to deliver learning materials innovatively. In this case, it is necessary to update the platform or learning media that will be used and a more personal approach to students so that they are more enthusiastic about participating in learning [2].

Not only that, the observation from the data on student learning outcomes in the previous semester showed that there were $25.7 \%$ of students who did not do the given assignments so that they had complete learning results data, thus the teachers were unable to recognize the abilities and activeness of students in the learning process which would affect the result [3].
Therefore, the teachers' performance in carrying out the learning process is the main factor of students success [4]. To develop a better performance, one methods that can be used is to conduct Classroom Action Research (CAR) [5]. This classroom action research is expected to apply a learning model that can improve students learning activities by applying the assisted learning model.

The assisted learning model is a learning model based on constructivism theory, meaning that knowledge is not something that is given naturally, but the formation of knowledge from the results of human activities [6]. This learning model is equipped with assistance, where other people will provide instructions and support in learning needed to improve students' intellectual development optimally [7]. If the cognitive development of students develops optimally, it will affect the psychomotor domain of the students themselves, in other words where the real manifestation of students' psychomotor results is a continuation of the students' cognitive and affective learning outcomes [8]. 
In using this assisted learning model, students can be more active in asking their teachers or other students who are more capable without fear if they experience difficulties [9] and can make the relationship between teachers and students closer in the learning process [10]. This is intended so that students are more active and enthusiastic during the learning process [11]. In line with the previous statement, the teacher's wisdom is expected to reflect a humble, generous, and forgiving attitude towards their students if during the learning process they ask questions or consult about material they do not comprehend yet. Teachers must be able to forgive all the shortcomings that exist in their students and accept them as they are [12].

\section{METHODS}

This classroom action research (CAR) was carried out in the 10th grade of construction and property business skills competency at Vocational High School Jakarta which amounted to 16 students who drew using AutoCAD software. This research was conducted in the second semester of the 2020/2021 academic year from January to June 2021. To be more precise, this research was conducted from the 16th meeting until the 18th meeting on the section drawing subject.

The research methodology that is used for this research is a mixed method. Mixed method can be used when; (1) the use of quantitative or qualitative approach does not help the researcher to comprehend the problem in their research; (2) the obtained results through quantitative or qualitative approach are not sufficient to explain the existing results, in which additional interpretations are needed; (3) qualitative data requires quantitative approach for completion [13].

The researchers used mixed-method sequential explanatory [14], where the first stage is to conduct direct observation in the class to obtain the qualitative data on student learning activity, then existing qualitative data is processed into quantitative data to measure the percentage (\%) of student's learning activity during the learning process. The procedure for CAR used in this research followed the theory by Kemmis and McTaggart [15] with the following cycle:

\subsection{Cycle I}

\subsubsection{Planning}

In this stage, the researcher planned and prepared everything which supported the course of the research, such as preparing the lesson plan, section drawing materials in the form of an information book for the pieces, and AutoCAD files in the form of PDF as examples for the finished house pieces, the student learning activity observation sheet, the student assignments, and distributed the subject through Google Classroom.

\subsubsection{Cycle I Action}

In cycle I, CAR was held for two class meetings and was carried out for 3 x 30 minutes each meeting. All the stages for cycle I includes:

1. Introduction: The researcher joined a google meet class, introduced themself to the class, shared an attendance list, lesson materials, and technical stuff for the lesson.

2. Core Activity: The researcher shared a share screen, demonstrated transverse section drawing using AutoCAD software, did a question-andanswer session and requested the students to show an example using AutoCAD software. However, only four students participated.

3. Closing: Concludes the lesson, given out assignments in the form of drawing transverse section drawings of simple houses using AutoCAD software, and ended the lesson.

4. Apart from class hours: The researcher also assisted students apart from class hours, they were given a consultation regarding the use of AutoCAD software and shared the recording of the class. The time for this assistance carried out from 7 AM until 8 PM every day. Each assignment was given one week to be executed.

\subsubsection{Observation}

During the implementation of assisted learning method, the researcher was accompanied by observers to observe the students' involvements in class activity.

\subsubsection{Reflection}

At this stage, the researcher with observers as well as the teachers discussed the results of the applied CAR for two meetings in one cycle. The result from cycle I concluded that the applied assisted learning model at this point is not yet optimized, students are not used to this system yet, the researcher demonstrated transverse section drawing too fast that the students couldn't understand, the students' involvements in class activity is lower than expected, problematic attendance list link, and use less assistance to the students.

\subsection{Cycle II}

Based on the reflection from Cycle I, there are a couple of methods that changed for a significant CAR result.

\subsubsection{Planning}

The researcher added more improvement to the implementation learning plan used in Cycle I, and the focused lesson for this cycle are drawing of elongated piece drawing material and longitudinal sections of simple houses. The researcher also recorded all the classes. 


\subsubsection{Cycle II Action}

Same as Cycle I, CAR was held for two class meetings and was carried out for $3 \times 30$ minutes each meeting. All the stages for cycle II included:

1. Introduction: The researcher joined a google meet class, introduced themself to the class, shared an attendance list, lesson materials, and technical stuff for the lesson

2. Core Activity: The researcher shared a share screen, demonstrated transverse section drawing using AutoCAD software but only half of it; the researcher wanted to test out the ability of the student to remember the previous lesson, did a question-and-answer session and requested the students to show an example using AutoCAD software.

3. Closing: Concludes the lesson, given out assignments in the form of drawing transverse section drawings of simple houses using AutoCAD software, and ended the lesson.

4. Apart from class: Unlike cycle I where researcher shared the recording of the class, in this cycle researcher didn't share any recording in hope that the students could learn by themselves.

\subsubsection{Observation}

During the implementation of assisted learning method, the researcher was accompanied by observers to observe the students' involvements in class activity. In this cycle, more students are more involved in class activity.

\subsubsection{Reflection}

At this stage, the researcher with observers as well as the teachers discussed the results of the applied CAR for two meetings in one cycle. The result from cycle II concluded that the applied assisted learning model at cycle II is better than cycle I. Both the researcher and the students are more used to this system. Because the researcher didn't fully demonstrated drawing, many students asked for assistance apart from class hour, they get more curious and active. More students also dressed in uniform than before, even though they only turned on the camera when they were asked for attendance. The students' involvements in class activity have improved and reached the indicator for successful research, so there was no other improvement needed.

The criteria for success in this research is when a student's learning activity is said to increase if the average results of the percentage of student's learning activity is at least $55 \%$. This figure is obtained based on the discussion with the teacher in charge of the Technical drawing lesson. Table 1 is the variables and indicators that will be used to measure student activity.
Table 1. Student observation instrument

\begin{tabular}{|l|l|l|}
\hline $\begin{array}{l}\text { Variable of } \\
\text { Activity }\end{array}$ & Indicator of Activity & Number \\
\hline Emotional & $\begin{array}{l}\text { Turning on the camera } \\
\text { during the lesson } \\
\text { Wearing a uniform when } \\
\text { learning process takes } \\
\text { place }\end{array}$ & 1 \\
\hline $\begin{array}{l}\text { Mental } \\
\text { activities }\end{array}$ & $\begin{array}{l}\text { Responding to the teacher } \\
\text { during the lesson }\end{array}$ & 2 \\
\hline $\begin{array}{l}\text { Oral } \\
\text { activities }\end{array}$ & $\begin{array}{l}\text { Asking questions related to } \\
\text { learning materials }\end{array}$ & 3 \\
\hline $\begin{array}{l}\text { Motor } \\
\text { activities }\end{array}$ & $\begin{array}{l}\text { Doing consultation on } \\
\text { working on the } \\
\text { assignments apart from } \\
\text { lesson hours }\end{array}$ & 4 \\
\hline
\end{tabular}

Data collection technique for this research is as follow:

1. Interview

2. Observation: The researcher used this percentage formula to measure the result of the observation of student's learning activity:

Calculation: $\frac{\sum \text { each indicator }}{\sum \text { category } x \sum \text { students }} \times 100 \%$

3. Documentation

4. Field Notes

5. Open-ended Question

Afterwards, to indicate the student's learning activity according to [16] is based on this following table 2:

Table 2. Criteria based on student performance

\begin{tabular}{|c|c|}
\hline Performance & Criteria \\
\hline $75 \%-100 \%$ & Very high \\
\hline $51 \%-74 \%$ & High \\
\hline $25 \%-50 \%$ & Moderate \\
\hline $0 \%-24 \%$ & Very low \\
\hline
\end{tabular}

Validation for non-test research instruments such as observation is ample to use construct validity. In this case, the experts will give their opinion on the instruments that have been prepared by the researcher [16].

Data validation is the truth of an on-going research process where the validity of this data can be used as a base for drawing solid conclusions. In this research, the researcher used source or data triangulation which means collecting data from various sources [17]. 
The data analysis technique that was chosen for this research by the researcher is descriptive-comparative. Descriptive means that the researcher explains certain relationship, makes hypotheses, and collects the significance of the problems are being researched [18]. This research examines the student's learning activity during the technical drawing lesson. On the other hand, comparative means searching for an answer to the cause and effect of a problem by analyzing the factors that caused the problem to occur.

\section{RESULT}

Data triangulation was carried out from various sources such as interviews, direct observation, documentation, and field notes. A total of 16 students and 1 teacher of Engineering Drawing subject were involved in this research.

After the data was collected through various sources, the obtained information is that during the lesson of Technical Drawing took place, before the classroom action research (CAR) was conducted using assisted learning model, the learning model that was applied is discovery learning. In terms of active learning, the students were still considered less active due to many factors, such as the students were still on a transition phase from junior high school to senior/vocational high school. Moreover, the students' limitations in terms of facilities, media, internet data, and inadequate gadget.

In addition, the number of students who do not turn on their camera during the learning process is also caused by several factors. Most students stated they felt embarrassed; their camera device is not good enough, the home environment that is not supportive, and bad internet signal. However, there are small number of students who want to turn their camera on, but they felt shy if they are the only one who turn it on. This is in line with the result of the direct observations that have been carried out for two cycles during the learning process, none of the students turned on their camera except when requested while taking attendance.

Meanwhile, in terms of responding to the teacher during the learning process, most students states that they felt shy, needed more time to understand the question, and had bad internet connection so the voices were not heard clearly. Therefore, to face these issues, the teacher of Technical Drawing lesson said that by calling each student's name could monitor their presence, so that the students would respond to the teacher. However, this too has become a limitation that cannot be enforced due to various factors that have been described earlier.

In accordance with the previous paragraph, in the case of asking questions regarding the related lesson materials, students answered that they feel more comfortable in asking through WhatsApp. The reasons are varied, ranging from they feel embarrassed if asking through Google Meet, then they feel more personal if asking questions by WhatsApp, they are afraid to get labelled as 'know-it-all' by their peers, and they also added that asking questions through WhatsApp can be done anytime, more time-efficient and it is not data consuming. Nevertheless, many of the students also prefer to ask during the learning process on Google Meet, because they will get clearer and more detailed answer that is being explained by the teacher, as well as they can respond directly.

Furthermore, in the case on conducting consultations apart from lesson hours, there are a small number of students who have high initiative in doing assignments, and their frequency of asking questions is greater when compared to other students. The questions asked were like they were motivated in doing their assignments ahead of time because they consider the technical drawing lesson is easier than other lessons. Then, one of the students answered that s/he needed to improve the grades in concentration subjects because that student felt left behind in other subjects, and in this Technical Drawing Lesson s/he felt that $\mathrm{s} /$ he could outperform the other peers, and that became a motivation. Thus, the teacher of Technical Drawing lesson said that he had no problem if the students had consultation apart from lesson hours. He said that it is one of his responsibilities as a teacher to guide his students and he must be ready every time.

Moreover, according to [19], teachers as educators must have personality competencies and have wisdom to face their students. Modest, generosity, and forgiveness are expected to be some of the qualities that exist in the teachers when dealing with students who ask questions or consult regarding material or assignments that they do not understand yet. Appreciating students and treating them as a human being is also one of the wisdoms that must be possessed by the teachers.

Based on the theory of mastery learning proposed by [20], it aims to make teaching materials are fully mastered and understood by the students. Mastery learning also means that there are no more school activities apart from lesson hours. This theory is expected to overcome the weakness in the learning system so that there will be no more intelligent students who will achieve learning objectives completely, yet it does not apply to students who are less smart. In fact, the use of this assisted learning model is contrary to the theory mentioned earlier, because assisted learning model requires students to consult apart from lesson hours and the teachers are also willing to cater for it.

Therefore, there are consequences and risks in using this assisted learning model. One of the consequences is that the teachers have to cater to the students who ask for consultation and lose the time to spend with their family who also need the attention, affection, love, and not to mention that they will also have inadequate rest 
time. The risk that can be faced by the students is that they lose the time for themselves, such as socializing with other friends and having a day off. Thus, one of the recommendations to anticipate these things from occurring is to limit consultation time apart from lesson hours where the time to conduct the consultation should not exceed the teachers' working hours.

Next, the increase in student's learning activity as a whole and observed directly from each indicator can be seen table 3 :

Table 3. Indicator Results Measured from pre-cycle to cycle 2

\begin{tabular}{|l|l|l|l|l|}
\hline $\begin{array}{l}\text { N } \\
\text { O. }\end{array}$ & $\begin{array}{l}\text { Indicator } \\
\text { activity }\end{array}$ & $\begin{array}{l}\text { Pre- } \\
\text { cycle }\end{array}$ & $\begin{array}{l}\text { Cycle } \\
\text { I }\end{array}$ & Cycle II \\
\hline 1. & $\begin{array}{l}\text { Readiness to } \\
\text { follow the lesson }\end{array}$ & $37.5 \%$ & $\begin{array}{l}58.59 \\
\%\end{array}$ & $67.19 \%$ \\
\hline 2. & $\begin{array}{l}\text { Respond to the } \\
\text { teacher }\end{array}$ & $\begin{array}{l}29.69 \% \\
\text { related to lesson } \\
\text { materials }\end{array}$ & $\begin{array}{l}50 \% \\
\%\end{array}$ & $51.56 \%$ \\
\hline 4. & $\begin{array}{l}\text { Doing consultation } \\
\text { apart from lesson } \\
\text { hours }\end{array}$ & $\begin{array}{l}14.06 \% \\
\text { Actively asking } \\
\text { (low) }\end{array}$ & $\begin{array}{l}30.46 \\
\%\end{array}$ & $\begin{array}{l}65.62 \% \\
\text { (low) }\end{array}$ \\
\hline \multicolumn{2}{|l|}{ Average } & (moderate) \\
\hline
\end{tabular}

When the teacher asked why they were unwilling to turn on the camera, the majority answered because they were embarrassed and not used to it. However, this does not mean that they will be inactive in learning since they will be more confident because they only stare at their screen, not face-to-face with many people [21]. If seen from the characteristics of the student activity according to [22], the interactions that occur in learning must be multi-directional, and if the teacher asks questions, not only certain students who respond. However, if some of the students are not mentioned by the teacher, only certain students will respond. The third indicator explains that the increased students learning activity by the students are already trying to find information that will be used in solving a problem, not only depending on the teacher [23]. In the fourth indicator for pre-cycle, namely the initiative to ask apart from lesson hours because it has not yet applied assisted learning model, this explanation is in line with the approach used in the assisted learning model, which is scaffolding. [24] stated that the assistance provided is temporary, it is given until the students feel they are able to do their works or assignments by themselves.

In line with [25], the use of this assisted learning model has an effect in increasing student's learning activity, where students can ask questions without fear of the teacher or their peers if they face with difficulties in doing their assignments. The relationship between teachers and students also becomes closer [26]. An increase in student's learning activity has occurred and indicators of research success have been achieved as expected. In cycle II, the students and the teachers as researcher have begun to adjust to the learning model. Students have started to have the initiative to ask and consult regarding the assignments apart from lesson hours. The increase in student's learning activity that occurs shows that the implementation of the assisted learning model can be used by the teachers during technical drawing lesson.

\section{CONCLUSION}

Based on the result of Classroom Action Research (CAR) that has been carried out on Technical Drawing lesson in the first year of Construction and Property Business Skills Competency Class at Vocational High School Jakarta, it can be concluded that the assisted learning model applied during learning process can improve student's learning activities on Technical Drawing lesson.

Furthermore, according to the result of data triangulation, the information that can be obtained are; (1) the reasons the students are reluctant to turn on the camera are because they feel shy, inadequate camera, bad internet network, the home environment is crowded, and they are not confident; (2) the students did not respond to the teacher because of various factors, such as being satisfied with the material provided, embarrassed, confused to answer, taking longer to understand the questions, and disconnected internet network; (3) the inactivity of students in asking questions during the learning process was caused by several factors, such as they preferred to ask questions via WhatsApp because it is more personal and too shy to ask; (4) lastly, there are a small number of students who have high initiative in doing assignments first and conducting consultations outside of class hours. The reason given is because they liked technical drawing lessons, and want to improve their grades in concentration subjects.

\section{REFERENCES}

[1] C. Chisadza, M. Clance, T. Mthembu, N. Nicholls, and E. Yitbarek, "Online and face-toface learning: Evidence from students' performance during the Covid-19 pandemic," African Dev. Rev., vol. 33, no. S1, pp. S114S125, 2021, doi: 10.1111/1467-8268.12520.

[2] A. I. Wang and R. Tahir, "The effect of using Kahoot! for learning - A literature review," Comput. Educ., vol. 149, no. May 2019, p 
103818

2020 ,

doi:

10.1016/j.compedu.2020.103818.

[3] C. Coman, L. G. Țîru, L. Meseșan-Schmitz, C. Stanciu, and M. C. Bularca, "Online teaching and learning in higher education during the coronavirus pandemic: Students' perspective," Sustain., vol. 12, no. 24, pp. 1-22, 2020, doi: $10.3390 /$ su122410367.

[4] S. Dhawan, "Online Learning: A Panacea in the Time of COVID-19 Crisis," J. Educ. Technol. Syst., vol. 49, no. 1, pp. 5-22, 2020, doi: $10.1177 / 0047239520934018$.

[5] G. Mettetal, "The What, Why and How of Classroom Action Research," J. Scholarsh. Teach. Learn., vol. 2, no. 1, pp. 6-13, 2002.

[6] D. Arendale, "Understanding the Peer Assisted Learning Model: Student Study Groups in Challenging College Courses," Int. J. High. Educ., vol. 3, no. 2, pp. 1-12, 2014, doi: 10.5430/ijhe.v3n2p1.

[7] S. Sevenhuysen et al., "The Development of a Peer Assisted Learning Model for the Clinical Education of Physiotherapy Students.," J. Peer Learn., vol. 6, no. 1, pp. 30-45, 2013.

[8] R. M. Y. Helal, T. N. El-Dakhakhni, M. B. Shawer, and E. A. Taha, "Effect of Moving the Apiaries on Activity of Honeybee Colonies," J. Agric. Res. Tanta Univ, vol. 29, no. December, pp. 268-282, 2003.

[9] E. C. Rosencrum, E. E. Hildebrand, M. Negron, and C. Adkinson, "Complementary Teaching Strategies Anchored in the Peer-Assisted Learning Model," Athl. Train. Educ. J., vol. 16, no. 2, pp. 142-149, 2021, doi: 10.4085/1947380x-20-87.

[10] Z. Dong, H. Liu, and X. Zheng, "The influence of teacher-student proximity, teacher feedback, and near-seated peer groups on classroom engagement: An agent-based modeling approach," PLoS One, vol. 16, no. 1 January, pp. 1-19, 2021, doi: 10.1371/journal.pone.0244935.

[11] S. Rimm-Kaufman and L. Sandilos, "Improving students' relationships with teachers," Am. Psychol. Assoc., pp. 1-30, 2018.

[12] K. Stenberg and K. Maaranen, "The differences between beginning and advanced student teachers' teacher identities based on their practical theories," Educ. Inq., vol. 11, no. 3, pp. 196-210, 2020 ,

doi: 10.1080/20004508.2020.1716541.

[13] M. M. Archibald, A. I. Radil, X. Zhang, and W. E. Hanson, "Current mixed methods practices in qualitative research: A content analysis of leading journals," Int. J. Qual. Methods, vol. 14, no. 2, pp. 5-33, 2015, doi: $10.1177 / 160940691501400205$.

[14] N. V. Ivankova, J. W. Creswell, and S. L. Stick, "Using Mixed-Methods Sequential Explanatory Design: From Theory to Practice," Field methods, vol. 18, no. 1, pp. 3-20, 2006, doi: $10.1177 / 1525822 X 05282260$.

[15] S. Kemmis, R. McTaggart, and R. Nixon, Introducing Critical Participatory Action Research. 2014.

[16] H. Taherdoost, "Validity and Reliability of the Research Instrument; How to Test the Validation of a Questionnaire/Survey in a Research," SSRN Electron. J., no. September, 2018, doi: 10.2139/ssrn.3205040.

[17] N. Carter, D. Bryant-Lukosius, A. Dicenso, J. Blythe, and A. J. Neville, "The use of triangulation in qualitative research," Oncol. Nurs. Forum, vol. 41, no. 5, pp. 545-547, 2014, doi: 10.1188/14.ONF.545-547.

[18] F. Esser and R. Vliegenthart, "Comparative Research Methods," Int. Encycl. Commun. Res. Methods, pp. 1-22, 2017, doi: 10.1002/9781118901731.iecrm0035.

[19] K. Selvi, “Teachers' competencies," Cult. Int. J. Philos. Cult. Axiolog., vol. 7, no. 1, pp. 167175, 2010, doi: 10.5840/cultura20107133.

[20] S. Benjamin, E. Dhew, and B. S. Bloom, "Learning for Mastery," Encycl. Sci. Learn., no. 2, pp. 1854-1854, 2012, doi: 10.1007/978-14419-1428-6_4645.

[21] V. Gherheș, C. E. Stoian, M. A. Fărcașiu, and M. Stanici, "E-learning vs. Face-to-face learning: Analyzing students' preferences and behaviors," Sustain., vol. 13, no. 8, 2021, doi: 10.3390/su13084381.

[22] D. Mykota, "The impact of learner characteristics on the multi-dimensional construct of social presence," Turkish Online J. Educ. Technol., vol. 16, no. 2, pp. 137-144, 2017.

[23] S. Tientongdee, "Development of problemsolving skill by using active learning for student teachers in Introductory Physics," J. Phys. Conf. Ser., vol. 1144, no. 1, 2018, doi: 10.1088/17426596/1144/1/012002.

[24] K. S. Taber, "Scaffolding learning: Principles for effective teaching and the design of classroom resources," Eff. Teach. Learn. Perspect. Strateg. Implement., no. September 2018, pp. 1-44, 2018.

[25] S. Capstick, "Benefits and Shortcomings of Peer Assisted Learning ( PAL ) in Higher Education : an appraisal by students This paper is a working copy produced for the Peer Assisted Learning conference, January 2004 . Revisions are likely to precede submission of this ," Learning, no. January, 2004.

[26] G. Zhang, X. Yue, Y. Ye, and M. Y. P. Peng, "Understanding the Impact of the Psychological Cognitive Process on Student Learning Satisfaction: Combination of the Social Cognitive Career Theory and SOR Model," Front. Psychol., vol. 12, no. August, 2021, doi: 10.3389/fpsyg.2021.712323. 